\title{
PENGARUH PEMBELAJARAN TEMATIK BERBANTU MEDIA PEMBELAJARAN MULTIMEDIA INTERAKTIF DENGAN KONSEP “TRIHITAKARANA" TERHADAP PEMAHAMAN KONSEP IPA SISWA KELAS III SD DWIJENDRA DITINJAU DARI PENGETAHUAN AWAL SISWA
}

\author{
Oleh: \\ I Made Astra Winaya \\ Prodi Pendidikan Guru Sekolah Dasar (PGSD) \\ Fakultas Keguruan dan Ilmu Pendidikan Universitas Dwijendra Denpasar \\ winaya@undwi.ac.id
}

diterima 18 Maret 2019, direvisi 20 Maret 2019, diterbitkan 29 April 2019

\begin{abstract}
ABSTRAK
Tujuan penelitian ini untuk mengetahui pengaruh model pembelajaran tematik berbantu media interaktif berkonsep Trihita Karana terhadap pemahaman konsep IPA ditinjau dari pengetahuan awal siswa. Penelitian ini merupakan penelitian eksperimen semu dengan rancangan posttest-only control group design. Populasi adalah seluruh siswa kelas III SD Dwijendra Denpasar. Sampel yang digunakan berjumlah 54 orang dibagi menjadi kelas kontrol dan kelas eksperimen dengan teknik random sampling. Analisis data menggunakan ANAVA dua jalur. Data pemahaman konsep dan pengetahuan awal siswa dikumpulkan melalui tes. Hasil penelitian menunjukkan bahwa model pembelajaran tematik berbantu media interaktif berkonsep Trihita Karana berdampak lebih baik terhadap pemahaman konsep siswa dibandingkan dengan model pembelajaran konvensional dan terdapat interaksi yang signifikan antara model pembelajaran dan pengetahuan awal siswa.
\end{abstract}

Kata Kunci: Pembelajaran Tematik, Trihita Karana, Pemahaman Konsep IPA, Pengetahuan Awal 


\section{PENDAHULUAN}

Pesatnya perkembangan dan pemanfataan teknologi digital di berbagai bidang kehidupan manusia yang menimbulkan terjadinya revolusi industry 4.0 yang tengah dihadapi oleh seluruh negara di dunia. Saat ini pemerintah Indonesia pun tengah fokus meningkatkan daya saing bangsa untuk dapat menghadapi revolusi industri 4.0 tersebut karena diprediksi memiliki potensi manfaat yang besar terhadap kemajuan negara. Berbagai kebijakan sedang dan telah dilakukan pemerintah dalam bidang pendidikan untuk meningkatkan kualitas sumber daya manusia, diantaranya. (1) Bidang manajeman pendidikan, yaitu: desentralisasi pendidikan (melalui program manajeman pendidikan berbasis sekolah). (2) Bidang kurikulum, yaitu penyempurnaan kurikulum KTSP dan kurikulum 2013. (3) Proses pembelajaran di SD, guru melaksankan pembelajaran tematik dengan pendekatan saintifik dan melakukan penilaian secara autentik. (4) Bidang profesional, yaitu mensertifikasi guru-guru untuk menjadi tenaga profesional, pemberian beasiswa bagi guru yang mengikuti program pascasarjana, memberikan pelatihanpelatihan keguruan, serta diimbangi dengan meningkatkan kesejahteraan taraf kehidupan guru. (5) Peningkatan anggaran pendidikan melalui bantuan dana oprasional sekolah (BOS) dan bantuan peralatan praktik sekolah. (6) dikeluarkannya PP No.87/2017 tentang Penguatan Pendidikan Karakter (PPK) di semua jenjang pendidikan. (7) Dikutip dari halaman unbk.kemendikbud.go.id, (2018) menyebutkan sejak tahun 2017, sejumlah 30.577 sekolah yang terdiri dari 11.096 SMP/MTs, 9.652 SMA/MA dan 9.829 SMK mulai melaksanakan Ujian Nasional Berbasis Komputer (UNBK) secara masif.

Berdasarkan urain tersebut, pemerintah mulai memandang serius pengembangan lembaga pendidikan karana memiliki peranan peting dalam mewujudkan sumber daya manusia yang berkualitas dan kompetitif. Akan tetapi, semua hal tersebut tidak akan menunjukan hasil yang optimal apabila pola pikir sentralistik dan monolitik masih mewarnai pengemasan dunia pendidikan di negeri ini. Menurut Natajaya dan Dantes (2015) menjelaskan dunia pendidikan dewasa ini terlihat adanya kecenderungan pendidikan yang dilakukan semata-mata untuk penguasaan iptek merupakan suatu realitas yang harus disikapi, karena pendidikan tidak boleh hanya didasarkan pada penguasaan iptek saja, tetapi harus dikombinasi diorkestra secara terpadu dengan nilainilai kemanusiaan. Sejalan dengan itu, Winaya (2017) menyampaikan pendidikan dengan pola yang hanya menekankan knowlage, membawa dampak terhadap meningkatnya perilakuperilaku menyimpang pada siswa. Untuk itu, reformasi lembaga pendidikan hendaknya membawa semangat pendidikan yang bermakna (meaningful learning). Bermakna artinya siswa akan memahami konsep-konsep yang mereka pelajari itu melalui pengalaman langsung dan menghubungkannya dengan konsep lain yang sudah mereka pahami.

Pendidikan bermakna bagi siswa akan terwujud apabila pembelajaran yang dilaksanakan berpusat pada siswa (student center). Hal tersebut sejalan dengan spirit dari pengimplementasian Kurikulum 2013 sebagai bentuk pembaharuan dan penyempurnaan kurikulum sebelumnya menghendaki pembelajaran yang berpusat pada siswa (student center) dengan pendekatan tematik (Winaya, 2016). Menurut Natajaya dan Dantes (2015) mengungkapkan pembelajaran tematik adalah pembelajaran terpadu yang menggunakan tema sebagai pokok atau kajian yang memungkinkan dapat mengaitkan atau mengintegrasikan 
http://ejournal.ihdn.ac.id/index.php/AW

pencapaian tujuan-tujuan belajar beberapa mata pelajaran terkait sehingga memberikan pengalaman belajar secara langsung dan powerful kepada anak didik. Tema digunakan sebagai pokok pikiran atau gagasan pokok yang dijadikan pokok pembahasan dalam pembelajaran yang berkaitan dengan pengalaman anak didik. Selajan dengan itu, Karli (2015) menjelaskan pembelajaran tematik sebagai suatu pendekatan belajar mengajar yang melibatkan beberapa mata pelajaran dalam satu tema untuk memberikan pengalaman bermakna bagi siswa. Pengalaman bermakna maksudnya anak memahami konsep - konsep yang telah mereka pelajari itu melalui pengalaman langsung dan menghubungkannya dengan konsep lain yang sudah mereka pahami. Selain itu, dalam pembelajaran tematik guru dituntut inovatif dalam mengemas pembelajaran di kelas. Menurut Iskandar (2008) semakin inovatif guru maka semakin baik pula kemampuannya mengelola pembelajaran.

Namun fakta dilapangan menunjukan, proses pembelajaran di sekolah masih jauh dari yang diharapkan. Hal tini diperkuat dari hasil penelitian Wasis (2015) yang memberikan analisis penyebab kurang memuaskan capaian pembelajran disebabkan karena siswa hanya berhasil menyelesaikan permasalahan yang sudah dikenal, dengan informasi pendukung yang telah tersedia. Fakta tersebut menunjukkan bahwa siswa Indonesia hanya mampu menyelesaikan routine problem (permasalahan rutin) dan mengalami kesulitan ketika menghadapi masalah nonroutine problem (permasalahan non rutin). Kesulitan meliputi pemecahan masalah melalui penalaran dalam soal pengamatan tentang konsep sains. Siswa hanya mampu memahami beberapa fakta terkait konsep dasar fenomena alam. Belum mampu melaporkan dan menghubungkan berbagai konten pengetahuan, apalagi menerapkan konsep-konsep yang kompleks dan abstrak.

Kegiatan pembelajaran yang dilaksanakan cendrung monotun dan kovensional ditenggarai sebagai faktor penyebab siswa mengalami kesulitan tersebut. Menurut pendapatnya Winaya (2013:2) mengungkapkan model pembelajran konvensional yang menekankan ceramah kurang mampu merangsang siswa untuk terlibat secara aktif dalam proses pembelajaran. Sejalan dengan itu, menurut Lasmawan (2010: 128) suasana belajar dengan model konvensional akan semakin menjauhkan pencapaian tujuan pembelajaran yang hendak ingin dicapai. Berdasarkan hal tersebut, konsep-konsep pembelajaran yang saling terkait sehingga memerlukan keterampilan melakukan penalaran agar siswa dapat memahaminya secara utuh sehingga dapat diaplikasikan dalam memecahkan sebuah permasalahan. Dalam taksonomi Bloom, pemahaman berada pada level comprehension. Pemahaman konsep memiliki peranan penting dalam proses pembelajaran dan merupakan dasar dalam mencapai hasil belajar. Pemahaman konsep memiliki definisi beragam, tergantung dari bidang kajian ilmu masing-masing. Holme, Luxford, \& Brandriet (2015) menyimpulkan definisi pemahaman konsep dalam konteks IPA berdasarkan pendapat para pakar adalah kemampuan siswa dalam memahami hubungan konsep satu sama lain sehingga bisa diterapkan untuk memecahkan masalah. Pemahaman konsep yang kurang mapan dapat ditandai dengan tidak memahami makna konten pengetahuan, definisi, dan alasan dari bagian pengetahuan yang saling terkait. Untuk itu, perlu dilakuan perbaikan kualiatas pembelajaran di kelas dengan pendekatan yang lebih inovatif. 
Pembelajaran tematik merupakan pendekatan pembelajaran yang mengintegrasikan berbagai kompetensi dari berbagai mata pelajaran ke dalam berbagai tema. Pengintegrasian tersebut dilakukan dalam dua hal, yaitu integrasi sikap, keterampilan dan pengetahuan dalam proses pembelajaran dan integrasi berbagai konsep dasar yang berkaitan. Tema merajut makna berbagai konsep dasar sehingga peserta didik tidak belajar konsep dasar secara parsial melainkan memberikan makna yang utuh siswa, seperti yang tercermin pada berbagai tema yang tersedia. Serta jika ditinjau dari psikologi pembelajaran, anak SD berada pada tahap operasional kongkrit sehingga pemebelajaran tematik yang dilaksanakan diupayakan menggunakan media pembelajaran untuk membantu proses pencapaian tujuan pembelajaran (Winaya, 2018). Untuk itu, dalam penelitian ini, peneliti mencoba mengkombinasikan pembelajaran tematik dengan penggunaan media pembelajaran multimedia interaktif dengan konsep Tri Hita Karana. Media pembelajran ini, menggabungkan dan mensinergikan semua media yang terdiri dari teks, grafis, foto, video dan animasi yang menggambarkan cara menjaga keharmonisan hungan manusia dengan manusia, manusia dengan alam dan manusia dengan Tuhan yang merupakan konsep dari ajaran Tri Hita Karana. Sejalan dengan hal tersebut Azhar (2011: 26) menyatakan fungsi dari media pembelajaran dalam pembelajaran, sebagai berikut: (1) Media pembelajaran dapat memperjelas penyajian pesan dan informasi. (2) Media pembelajaran dapat meningkatkan dan mengarahkan perhatian siswa sehingga menimbulkan motivasi. (3) Media pembelajaran dapat mengatasi keterbatasan indera, ruang dan waktu. (4) Media pembelajaran dapat memberikan kesamaan pengalaman kepada mahasiswa tentang peristiwa dilingkungan mereka.
http://ejournal.ihdn.ac.id/index.php/AW

Mengacu pada hasil penelitian terdahulu, pembelajaran tematik mampu meningkatkan minat dan hasil belajar siswa (Sukerti, 2015). Pembelajaran tematik memberikan hasil pembelajran menjadi lebih bermakna dan sesuai kebutuhan anak (Natajaya \& Dantes, 2015). Pemahaman konsep IPA pada siswa usia operasional konkret menuju formal menjadi optimal (Capobianco \& Tyrie, 2009, p.1). Proses pemecahan masalah tersebut berpengaruh signifikan terhadap perkembangan intelektual siswa (James, 2012). Pemahaman konsep mengalami peningkatan karena kemampuan menalar siswa berkembang (Jackson \& Martin, 2014). Berdasarkan latar belakang tersebut maka penelitian ini bertujuan untuk menganalisis pengaruh pembelajaran tematik berbantu media interaktif berkonsep Trihita Karana terhadap pemahaman konsep IPA siswa SD yang dinjau dari pengetahuan awalnya.

\section{METODE}

Pelitian ini merupakan jenis penelitian quasi eksperimen karena keterlibatan sampel penelitian tidak dilakukan secara acak, melainkan dengan menggunakan kelas-kelas yang sudah ada, baik sebagai kelompok eksperimen maupun sebagai kelompok kontrol (Bes, 1982 dalam Sugiyono 2010). Dengan memperhatikan variabel-variabel yang terkait, rancangan penelitian yang digunakan adalah rancangan penelitian eksperimen dalam bentuk Post-Test Only Control Group design. Penelitian ini dilaksanakan di SD Dwijendra Denpasar. Populasi penelitian meliputi seluruh siswa kelas III yang ada di SD Dwijendra yang merupakan kelas parallel. Sebaran siswa pada setiap kelas dilakukan secara merata yaitu terdiri atas siswa yang memiliki kemampuan tinggi, sedang, dan rendah yang di lihat dari nilai raportnya.

Penelitian ini memerlukan data tentang pengetahuan awal siswa dan data 
tentang pemahaman konsep IPA siswa. Untuk mengumpulkan kedua data tersebut digunakan metode tes. Data pengetahuan awal siswa dikumpulkan sebelum perlakuan diberikan dengan menggunakan tes pemahaman konsep. Sedangkan data pemahaman konsep IPA siswa dikumpulkan dengan menggunakan tes pemahaman konsep IPA dengan bentuk uraian. Kriteria penilaian tes pemahaman konsep menggunakan rubrik yang memiliki rentangan skor 0-5.

Untuk mendeskripsikan data penelitian dipergunakan teknik analisis statistik deskriptif dan untuk menguji hipotesis penelitian yang diajukan digunakan teknik analisys of covariance (anava) dua jalur. Uji prasyarat analisis yang digunakan adalah; 1) Uji normalitas sebaran data, 2) Uji homoginitas varian, dan 3) Pengujian hipotesis dengan teknik analisis varians (anava) dua jalur dengan uji-F.

\section{HASIL DAN PEMBAHASAN PENELITIAN}

Berdasarkan hasil analisis dan pengujian hipotesis melalui metode satistik dengan menggunakan alaisisi anakova dua jalur, diperoleh hasil penelitian yang dapat dijabarkan sebgai berikut.

Pertama, Terdapat perbedaan pemahaman konsep IPA siswa antara siswa yang mengikuti pembelajaran dengan pembelajaran tematik berbantu media interaktif berkonsep Trihita Karana dan siswa yang mengikuti pembelajaran dengan model belajar konvensional $\left(\mathrm{F}_{\mathrm{A}}=6,394\right.$ dengan $\mathrm{p}<$ 0,05). Rata - rata pemahaman konsep IPA siswa yang mengikuti pelajaran dengan model pembelajaran konflik kognitif lebih besar daripada model pembelajaran konvensional $\left(\overline{\mathrm{x}}_{\mathrm{A} 1}=39,630\right.$ $\left.>\overline{\mathrm{x}}_{\mathrm{A} 2}=37,478\right)$.
http://ejournal.ihdn.ac.id/index.php/AW

Kedua, Terdapat pengaruh interaksi antara model pembelajaran dan pengetahuan awal terhadap pemahaman konsep IPA $\left(\mathrm{F}_{\mathrm{AB}}=110,196\right.$ dengan $\mathrm{p}<0,05)$.

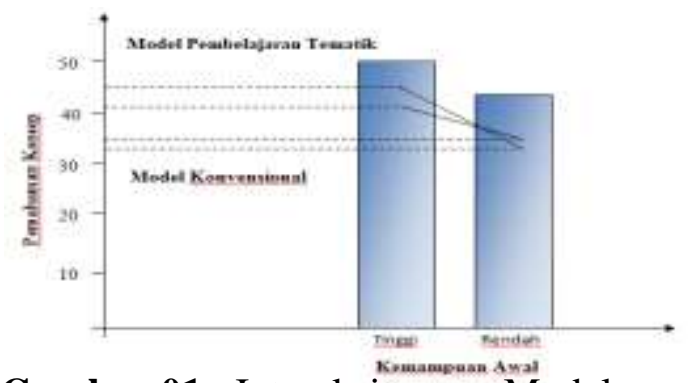

Gambar 01. Interaksi antara Model Pembelajaran dengan Pengetahuan Awal Terhadap Pemahaman Konsep IPA.

Berdasarkan gambar di atas, terlihat bahwa pada siswa yang memiliki pengetahuan awal tinggi rata-rata skor pemahaman konsep IPA siswa yang mengikuti pelajaran dengan menggunakan model pembelajaran tematik berbantu media interaktif berkonsep Trihita Karana lebih tinggi daripada pemahaman konsep IPA siswa yang mengikuti pelajaran dengan model pembelajaran konvensional. Sedangkan pada siswa yang memiliki pengetahuan awal rendah, rata-rata pemahaman konsep IPA siswa yang mengikuti pelajaran dengan model pembelajaran konvensional lebih tinggi daripada pemahaman konsep IPA siswa yang mengikuti pelajaran dengan model pembelajaran tematik berbantu media interaktif berkonsep Trihita Karana.

Ketiga, Pada siswa yang memiliki pengetahuan awal tinggi, terdapat perbedaan pemahaman konsep IPA siswa antara siswa yang mengikuti model pembelajaran tematik berbantu media interaktif berkonsep Trihita Karana dan siswa yang mengikuti model pembelajaran konvensional $\left(\mathrm{Q}_{\text {-hitung }}=\right.$ $13,026>\mathrm{Q}_{\text {-tabel }}=3,900$ ). Pada siswa yang memiliki pengetahuan awal tinggi, 
rata - rata pemahaman konsep IPA siswa yang mengikuti model pembelajaran tematik berbantu media interaktif berkonsep Trihita Karana lebih besar daripada siswa yang mengikuti pembelajaran konvensional $\left(\overline{\mathrm{x}}_{\mathrm{A} 11}=\right.$ $44,957>\overline{\mathrm{x}}_{\mathrm{A} 21}=33,870$ ).

Keempat, Pada siswa yang memiliki pengetahuan awal rendah, terdapat perbedaan pemahaman konsep IPA siswa antara siswa yang mengikuti model pembelajaran tematik berbantu media interaktif berkonsep Trihita Karana dan siswa yang mengikuti model pembelajaran konvensional ( $\mathrm{Q}_{\text {-hitung }}=$ 7,969> $\left.\mathrm{Q}_{\text {-tabel }}=3,900\right)$. Pada siswa yang memiliki pengetahuan awal rendah rata rata pemahaman konsep IPA siswa yang mengikuti model pembelajaran konvensional lebih besar daripada siswa yang mengikuti pembelajaran tematik berbantu media interaktif berkonsep Trihita Karana $\overline{\mathrm{x}}_{\mathrm{A} 22}=41,087>\overline{\mathrm{x}}_{\mathrm{A} 12}=$ 34,304).

Berdasarkan uraian hasil uji hipotesis di atas, secara keseluruhan dengan tidak memperhatikan variabel kendali berupa jenis kelamin, pemahaman konsep IPA siswa yang mengikuti pembelajaran dengan model pembelajaran tematik berbantu media interaktif berkonsep Trihita Karana lebih tinggi bila dibandingkan dengan hasil belajar siswa yang mengikuti pembelajaran dengan model pembelajaran belajar konvensional. Hal tersebut menunjukan bahwa model pembelajaran tematik berbantu media interaktif berkonsep Trihita Karana salah satu model pembelajaran yang lebih unggul dari strategi konvensional. Pada model pembelajaran tematik berbantu media interaktif berkonsep Trihita Karana pembelajaran difokuskan pada siswa dan perbedaannya dengan strategi konvensional adalah siswa hanya menjadi objek dalam pembelajaran. Selain itu, Pembelajaran tematik bersifat
http://ejournal.ihdn.ac.id/index.php/AW

luwes (fleksibel) di mana guru dapat mengaitkan bahan ajar dari satu mata pelajaran dengan mata pelajaran yang lainnya, bahkan mengaitkannya dengan kehidupan siswa dan keadaan lingkungan tempat sekolah dan siswa berada. Sehingga dengan model pembelajaran seperti ini siswa mampu memahami materi secara keseluruhan (holistik), bermakna, dan mampu meningkatkan minatnya.

Berdasarkan hasil pengamatan peneliti bahwa dengan menerapkan model pembelajaran tematik berbantu media interaktif berkonsep Trihita Karana siswa merasa senang mengikuti proses pembelajaran, lebih cepat memberikan respons, lebih berani mengungkapkan pendapat, lebih kritis dalam adu pendapat dan menghargai pendapat teman yang mengalami kesulitan dalam memahami, siswa lebih mudah menerapkan pengalaman dan pengetahuan mereka, khususnya pemahaman konsep IPA untuk memecahakan sutu permasalahan. Kunci kesuksesan pembelajaran tematik berbantu media interaktif berkonsep Trihita Karana karena menggunakan prinsip belajar sambil bermain dan menyenangkan. Pemberian apresiasi terhadap keberanian dan keberhasialan siswa terbukti mampu membangkitkan rasa percaya dirinya. Selain itu, dengan melakukan banyak latihan dan kreativitas siswa alan lebih berkembang.

Beberapa hal yang diduga menjadi penyebab siswa yang memiliki pengetahuan awal tinggi rata-rata skor pemahaman konsep IPA siswa yang mengikuti pelajaran dengan menggunakan model pembelajaran tematik berbantu media interaktif berkonsep Trihita Karana lebih tinggi daripada siswa yang mengikuti pelajaran dengan model pembelajaran konvensional. Dalam pembelajaran konvensional kurang memperhatikan pengetahuan awal siswa. Padahal 
pengetahuan awal merupakan modal besar yang dapat digunakan guru sebagai "jembatan" penghubung antara pengetahuan yang telah dimiliki siswa sebelum memasuki pembelajaran materi berikutnya yang lebih tinggi. Sehingga siswa memiliki bayangan secara kongkrit tetang hal yang akan dipelajari pada pembahasan materi tersebut. Jadi seorang siswa yang mempunyai kemampuan awal yang baik akan lebih cepat memahami materi dibandingkan dengan peserta didik yang tidak mempunyai kemampuan awal dalam proses pembelajaran. Hal tersebut diperkuat oleh hasil penelitian Astuti (2015) yang menunjukan pengetahuan awal siswa berpengaruh secara signifikan terhadap minat dan prestasi belajar siswa.

Mengembangkan pemahaman konsep IPA pada dasarnya adalah membantu siswa melihat bagaimana hubungan antara materi yang diharapkan untuk dipelajari dengan dirinya sendiri sebagai individu. Proses ini berarti bahwa menunjukkan pada siswa bagaimana pengetahuan atau kecakapan tertentu mempengaruhi dirinya. Bila siswa menyadari bahwa belajar merupakan suatu alat untuk mencapai beberapa tujuan yang dianggap penting dan bila siswa melihat bahwa hasil dari belajar akan membawa kemajuan pada dirinya, kemungkinan besar ia akan berminat untuk mempelajari sesuatu. Selaian itu, menurut hasil penelitian Sadiqin, dkk (2017) menunjukan peningkatan pemahaman konsep dipicu oleh perkembangan kemampuan menalar siswa dalam membentuk konsep yakni kemampuan abstaksi dan diskriminasi. Kemampuan abstaksi dan diskriminasi yang optimal memudahkan siswa untuk menghubungkan berbagai pengetahuan prosedural dan pengetahuan deklaratif yang diperlukan dalam memecahkan masalah.

Temuan penting penelitian ini
adalah terdapat perbedaan yanag signifikan terhadap pemahaman konsep IPA siswa antara siswa yang mengikuti pembelajaran dengan pembelajaran tematik berbantu media interaktif berkonsep Trihita Karana dan siswa yang mengikuti pembelajaran dengan model belajar konvensional. Artinya, bahwa model pembelajaran tematik berbantu media interaktif berkonsep Trihita Karana berhasil mendorong siswa untuk memeiliki penalaran dan menguasai suatu konsep yang dapat digunakan untuk membantunya dalam memecahan permasalahan. Oleh karena itu, temuan penelitian ini memberi implikasi terhadap aplikasi model pembelajaran, baik model pembelajaran tematik berbantu media interaktif berkonsep Trihita Karana maupun model konvensional dalam proses pembelajaran siswa kelas III SD Dwijendra Denpasar. Temuan ini, menimbulkan beberapa implikasi, yaitu:

Pertama, Guru sebagai ujung tombak pembelajaran, harus memiliki pengetahuan dan keterampilan dalam memilih, mengembangkan, dan menerapkan model pembelajaran yang sesuai dengan rumpun dan karakteristik disiplin ilmunya. Pendekatan pembelajaran yang dapat mengkondisikan dan memotivasi siswa untuk mengakses informasi yang diperlukan untuk pengembangan potensi diri dan mencintai budaya secara proporsoinal Pembelajaran dengan model pembelajaran tematik berbantu media interaktif berkonsep Trihita Karana akan menuntun siswa untuk memahami konsep dan generalisasi IPA yang diperlukannya sejak dini dalam suasana kelas yang benar-benar merupakan potret riil masyarakat.

Kedua, Implikasi hasil penelitian terhadap perencanaan dan pengembangan model pembelajaran. Model pembelajaran tematik berbantu media interaktif berkonsep Trihita Karana dapat diaplikasikan dalam perencanaan 
dan pelaksanaan model pembelajaran yang selama ini diterapkan, sehingga menambah banyak variasi model pembelajaran yang dapat diterapkan oleh guru. Bagi seorang guru membuat perencanaan pelaksanaan pembelajaran merupakan hal yang sangat penting dan suatu kewajiban, karena persiapan yang baik adalah awal dari keberhasilan.

Ketiga, Implikasi lain dari temuan penelitian ini adalah bahwa ternyata pengetahuan awal memiliki kontribusi yang signifikan terhadap pemahaman konsep IPA dengan menggunakan model tematik berbantu media interaktif berkonsep Trihita Karana, namun hal ini tentu memerlukan pembuktian lebih jauh, sehingga diperlukan penelitian lanjut untuk pengujian model ini secara lebih luas.

Keempat, Penelitian ini menemukan bahwa secara keseluruhan pemahaman konsep IPA siswa yang mengikuti pelajaran dengan menggunakan model pembelajaran tematik berbantu media interaktif berkonsep Trihita Karana lebih tinggi daripada pemahaman konsep IPA siswa yang mengikuti pelajaran dengan menggunakan model pembelajaran konvensional. Untuk itu, setiap guru sebaiknya menggunakan model tematik berbantu media interaktif berkonsep Trihita Karana dalam pembelajaran bila siswa memiliki pengetahuan awal tinggi.

Penerapan secara inovatif atara model model pembelajaran konflik kognitif dengan memperhatikan pengetahuan awal yang dimiliki siswa diduga dapat memberikan sumbangan alternatif dalam meningkatkanan pemahaman konsep siswa.

\section{SIMPULAN}

Berdasarkan hasil penelitian sebagaimana diuraikan di atas, maka dapat ditarik kesimpulan dari penelitian ini sebagai berikut: (1) Terdapat perbedaan pemahaman konsep IPA siswa antara siswa yang mengikuti pembelajaran dengan pembelajaran tematik berbantu media interaktif berkonsep Trihita Karana dan siswa yang mengikuti pembelajaran dengan model belajar konvensional. (2) Terdapat pengaruh interaksi antara model pembelajaran dan pengetahuan awal terhadap pemahaman konsep IPA. (3) Pada siswa yang memiliki pengetahuan awal tinggi, terdapat perbedaan pemahaman konsep IPA siswa antara siswa yang mengikuti model pembelajaran tematik berbantu media interaktif berkonsep Trihita Karana dan siswa yang mengikuti model pembelajaran konvensional. (4) Pada siswa yang memiliki pengetahuan awal rendah, terdapat perbedaan pemahaman konsep IPA siswa antara siswa yang mengikuti model pembelajaran tematik berbantu media interaktif berkonsep Trihita Karana dan siswa yang mengikuti model pembelajaran konvensional

Berdasarkan temuan penelitian, pembahasan, dan refleksi akademik terkait dengan beberapa teori sejenis, serta dengan pertimbangan karakteristik serta keunggulan komperatif yang dimiliki oleh model pembelajaran tematik berbantu media interaktif berkonsep Trihita Karana,maka dapat diformulasikan saran sebagai berikut: (1) konsep pembelajaran hendaknya disampaikan secara utuh kepada siswa sehingga konsep tersebut dapat dimanfaatkan untuk memecahkan permasalahan. (2) Hasil penelitian ini menunjukkan pemahaman kosep IPA siswa yang mengikuti model pembelajaran tematik berbantu media interaktif berkonsep Trihita Karana berbeda dengan siswa yang mengikuti model pembelajaran konvensional. Untuk itu model pembelajaran model pembelajaran tematik berbantu media 
interaktif berkonsep Trihita Karana perlu diperkenalkan den dikembangkan lebih lanjut kepada para guru, siswa dan praktisi pendidikan lainya sebagai alternatif pembelajaran.

\section{DAFTAR PUSTAKA}

Capobianco, B. M., \& Tyrie, N. (2009). Problem solving using design. Science and Children, 47 (2), 38-41.

Holme, T. A., Luxford, C. J \& Brandriet, A. (2015). Defining conceptual understanding in general chemistry. Journal of Chemical Education, 92 (9), 1477-1483.

Jackson, K, M \& Martin, S, M, W. (2014). Effect of problem solving strategy on secondary school students achievement in circle geometry in emuhaya district of vihiga county. Journal of Education, Arts and Humanities, 2 (2), 18-26.

James, A. O. (2012). Relationship between senior secondary schools students' achievement in mathematical problemsolving and intellectual abilities tests. European Scientific Journal, 8 (15), 169179.

Kemendikbud. 2018. Ujian Nasinal Bebbasis Komputer. Alamat web:

https://unbk.kemendikbud.go.id /tentang, di unduh 6 Maret 2019

Karli, Hilda. 2015. "Penerapan Pembelajaran Tematik SD di Indonesia". E-jurnal EduHumaniora vol 2 no 1 Tahun 2015. E-ISSN 25795457. Diunduh Tanggal 03 Agustus 2018.

Lasmawan.2010. Menelisik Pendidikan IPS dalam Persepektif Kontekstual Empirik.Singaraja: Mediakom Indonesia Press Bali.
http://ejournal.ihdn.ac.id/index.php/AW

Natajaya, I Nyoman dan Nyoman Dantes.2015. "Perancangan Model Transpormasi Pendidikan Teknohumanistik yang Terintegrasi dengan Pembelajaran Tematik Di Sekolah Dasar". Jurnal Pendidikan Ganesha. Vol.4 No.1 ISSN: 2303-288X. Singaraja: Undiksha Press.

Sadiqin, Ikhwan Khairu. 2017. "Pemahaman Konsep IPA Siswa SMP Melalui Pembelajaran Problem Solving pada Topik Perubahan BendaBenda di Sekitar Kita”. Jurnal Inovasi Pendidikan IPA, 3 (1), 2017, 52-62

Sugiyono. 2010. Metode Penelitian Pendidikan pendekatan kuantitatif, kualitatif dan $R$ \& D. Bandung: Alfabeta

Sukerti, N. 2015. " Pengaruh Pembelajaran Tematik Terpadu Melalui Pendekatan Saintifik Terhadap Minat Belajar dan Hasil Belajar Siswa Kelas IV SD Negeri 2 Tibubeneng Kuta Utara". E-Jurnal Pascasarjana Undiksha 2015. Diunduh Tanggal 12 Maret 2019

Wasis. (2015). Hasil pembelajaran sains di indonesia: problem \& upaya mengatasinya. Prosiding Seminar Nasional Pendidikan Sains yang diselenggarakan oleh Pascasarjana Unesa, tanggal 24 Januari 2015. Surabaya: Pascasarjana Unesa.

Winaya, I Made Astra. 2013. "Pengaruh Model ARCS Terhadap Hasil Belajar Ditinjau dari Motivasi Belajar Siswa pada Pembelajaran IPS di Kelas IV SD CHIS Denpasar". E-jurnal Pascasarjana Undiksha vol.3 Tahun 2013. Diunduh Tanggal 19 Juni 2015. 
ADI WIDYA: Jurnal Pendidikan Dasar Volume. 4, Nomor 1 April 2019

ISSN: 2527-5445

http://ejournal.ihdn.ac.id/index.php/AW

Winaya, I Made Astra. 2016. "Pengaruh Model Quantum Teaching terhadap Hasil Belajar ditinjau dari Keterampilan Berpikir Kritis Siswa pada Pembelajaran IPA di Kelas V SD N. 1 Selanbawak". Jurnal Kajian Pendidikan Widya Accarya FKIP Universitas Dwijendra ISSN NO. 2085-0018 Maret 2016.

Winaya, I Made Astra. 2017. "Efektifitas Pengembangan Nilai-nilai Karakter pada Peserta Pasraman Kilat Tingkat Dasar di Desa Pakraman Selanbawak, Kecamatan Marga, Kabupaten Tabanan, Bali. Jurnal Kajian Pendidikan Widya Accarya FKIP Universitas Dwijendra ISSN NO. 2085-0018 Oktober 2017.
Winaya, I Made Astra. 2018. "Pengembangan Media Pembelajaran Berbasis Multimedia Interaktif dengan Konsep Tri Hita Karana untuk Pembelajaran Tematik di SD Kelas III Gugus 6 Kecamatan Abiansemal, Badung, Bali”. Jurnal Kajian Pendidikan Widya Accarya FKIP Universitas Dwijendra ISSN NO. 2085-0018 Oktober 2018.

